\title{
The Effects of Pre-reading Activities on ESP Reading Comprehension
}

\author{
Minoo Alemi \\ Sharif University of Technology, Tehran, Iran \\ Email: alemi@sharif.ir \\ Saman Ebadi \\ Allameh Tabataba'i University, Tehran, Iran \\ Email: samanebadi@gmail.com
}

\begin{abstract}
The present study intended to investigate the effects of pre-reading activities on reading comprehension of $\mathrm{L} 2$ learners of science and technology majors. In this respect the following research question was under consideration: Will comprehension be facilitated if students are instructed through restoring to pre reading activities? To carry out this research, participants were selected on the basis of Michigan Test of English Proficiency, and were assigned into control and experimental groups. Members of each group were randomly assigned to one of the two experimental and Control groups. Data analysis conducted through $T$ -test statistical procedures. The findings revealed that better comprehension can be gained through restoring to pre-reading activities. In fact, experimental group which was exposed to pre-reading activities gained considerable abilities in comprehension than control group. Results of this study revealed that giving prior information through restoring to pre-reading activities might become a useful tool for teachers of ESP to facilitate the learner's reading comprehension ability. Some implications have been drawn for ESP material designers too. The computation and analysis of the T-test, provided us with empirical answers for the research question posed, and the effectiveness of employment of pre-reading activities in ESP reading comprehension ability was confirmed.
\end{abstract}

Index Terms - pre-reading activities, ESP, reading comprehension

\section{INTRODUCTION}

Studies of pre-reading activities for native speakers have demonstrated the facilitative effects of activating reader's prior knowledge relevant to understanding of the new text (Mayer, 1994). Not only do pre-reading activities prepare native speakers for the concepts that follow, but making the reading task easier and connecting the new concept more meaningfully to prior knowledge, pre-reading activities make reading a more enjoyable task (Hansen, 1981) Pre-reading activities are thus intended to activate appropriate knowledge structures or provide knowledge that the reader lacks. The present study intends to investigate the effects of pre-reading activities on comprehension of engineering students. It is hypothesized that employing the pre-reading activities would significantly improve student's ability in comprehension. For the realization of this objective two groups of participants were employed and put in the two experimental and Control groups. The comparison of mean scores made by subjects of the two groups provided evidence to the effect that whether the difference between teaching strategies, if any, were due to experimental treatment or sampling error. This study is an attempt to arrive at an empirical answer to the following research question and hypotheses:

RQ: Will comprehension be facilitated if students are instructed through restoring to pre-reading activities?

The results of this study paved the way for acceptance of the belief that giving related information of the text through restoring to pre-reading activities can have large impact on reading comprehension. So we will come up with some guidelines for ESP teachers and syllabus designers regarding reading pedagogy in the final section of the study.

\section{LITERATURE REVIEW}

A good deal of the current research in the field of EFL reading is embedded in a Psycholinguistics framework (Goodman, 1970, Coady, 1979). In this view, the reader is seen as an active processor of information, one who selects only the most productive cues from the printed page. One way of facilitating a reader's interaction with a text for triggering and building background knowledge is through pre-reading activities (Hudson, 1982). Pre-reading activities provide orientation to content and context. They vary with the nature of the text, the reader's purpose and context of situation (Wallace, 1992).

\section{A. Importance of Reading}

Most scholars would agree that reading is one of the most important skills for educational and professional success (Alderson, 1984). In highlighting the importance of reading comprehension Rivers (1981:147) stated that " reading is 
the most important activity in any language class, not only as a source of information and a pleasurable activity, but also as a means of consolidating and extending one's which are knowledge of the language".

Reading reinforces the learner's other language skills. Krashen (1981) confirms that those who read more, have larger vocabularies, do better on test of grammar and write better (Kim \& krashen, 1997). Chastian (1988:218) while accepting the significance of reading for meaning claimed that all reading activities serve to facilitate communication fluency in each of the other language skills.

According to Eskey (1988), in advanced levels of second language the ability to read the written language at a reasonable rate and with good comprehension has long been recognized to be as oral skills if not more important.

\section{B. Interactive View of Reading and its Relationship with ESP}

A significant body of literature posits that reading is an interactive process (Carrell, Devine \& Eskey 1988; Grabbe, 1991; Rumelhart \& Ortony 1977). According to Grabbe (1991:385) the notion of reading as an interactive process refers to "a kind of dialogue between the reader and the text" The notion of reading as an interactive process evolved from the schema theory and is often termed top-down approach to reading. Carrell (1983) distinguishes between formal schemata the reader's knowledge of formal, rhetorical structure of the texts and content schemata - previous knowledge which the reader posses.

In an interactive model, the reader is not seen to progress in just one direction (bottom-up or top-down) in understanding the text, but as being able to alternate approaches as necessary (Barnett, 1989). The reader is seen as able to draw simultaneously from a variety of sources to understand the text such as lexical, orthographic, schematic, semantic, syntactical, and visual (Davies, 1995). Thus reading is seen as a simultaneous perceptual and cognitive process (Rumelhart \& Ortony, 1977). Interactive model of reading comprehension not only acknowledges the role of background knowledge, but also it stresses the significance of processing actual words of the texts. Goodman (1981:137) maintains that, " ... the goal of reading is constructing meaning in response to text. It requires interactive use of graphophonic, syntactic, and semantic cues to construct meaning." Although he is often referred to as a leading advocate of the top -down approach, his model by his own admission is interactive.

An interactive model of reading posited by Grabbe (1991) usually refers to interplay of both bottom-up and top-down reading strategies (Block, 1992). Bottom-up strategies include decoding graphic features and grammatical characteristics, while top-down strategies include predicting, applying background knowledge and recognizing global text structure. The notion of top-down strategies is usually used in the literature to include both global strategies for processing the text as well as activating conceptual knowledge of the world (Carrell, 1985 Shih, 1992).

According to Dubin and Bycina (1991), the interactive modal entails the reading processes to be as such that the visual data are transmitted to brain where they are matched with existing knowledge. Then on the basis of this experience, predictions are made about the content of the text, upon which, further sampling of the data are either confirmed or revised.

Anderson (1999) claims that "many teachers now accept the view that reading is the result of a two way communication between the reader and the text, achieved through simultaneous processing (which involves word recognition, sound/spelling correspondence etc.) and top-down processing (which involves skills like predication, inference etc.)

How do the above notions relate to ESP reading pedagogy? Grabbe's (1991) notion of reading as an interactive process implies that the ESP reader most probably has more limited content and formal schemata as well as less knowledge of language used in the text than the author has, thus, while an ESP reading course usually emphasizes building up student's knowledge of rhetorical structures and improving their knowledge of the target language. The gap in content schemata should not be ignored. The issue of ESP reading instructor as a content specialists raised in ESP literature (e.g. Robbinson, 1991). Grabbe's interactive model of reading dictates that ESP instruction should focus both on decoding language and on global reading strategies which (Duffy, 1988:763) defined them as "plans for solving problems, encountered in constructing meaning". They can be taught to students and when taught strategies help student's performance on tests of comprehension and recall.

\section{General Views on Pre-reading Activities}

The goals of Pre-reading stage are to activate the student's knowledge of the subject, to provide any language preparation that might be needed for coping with the passage and, finally to motivate the learners to want to read the text (Celce-Murcia, 1991). Tudor (1989) call pre-reading activities "enabling activities" because they provide a reader with the necessary background to organize activity and to comprehend the material (these experiences involve understanding the purpose (S) for reading and building a knowledge base necessary for dealing with the content and the structure of the material). They say that pre-reading activities elicit prior knowledge, and focus attention. Various techniques have been suggested by some authors (e.g. Greenall \& Swan, 1986) to mobilize existing knowledge including the use of pictures, movies and even role - plays. Research has not determined which of these is the most effective. So teachers are free to experiment according to the nature of reading material and inclinations of their classes (Carrell \& Eisterhold, 1983). In an academic setting, however, more formal techniques might be appropriate, of course different scholars listed different types of pre-reading activities, (Celce-Murcia, 1991:225) suggests, Word Association, Discussion and Text Surveys. 
Word association tasks generally involve eliciting from the students as many ideas as they can offer regarding the announced subject of the text. Normally their suggestions are written on the board and sometimes arranged into semantic map or "graphic organizer" which indicates how concepts are related to each other.

Discussions have also been found to activate what students know and through the exchange of information, to enhance their knowledge of the subject. Discussions can be initiated by simply posing questions about the content of the text or by using "anticipation guide" which is a series of statements often provocative in nature, which are intended to challenge student's knowledge and beliefs about the content of the passage (Celce-Murcia, 1991:225).

Nuttal (1982) claims that discussion promotes the active struggle with the text and students learn the processes of critical thinking that good readers use. Group work is ideal, because in small groups, even the weaker students should be active and learning. The procedure works in almost every level, and discussion can be in L1, if students cannot manage it in the FL.

Text Survey is often, but not exclusively, used with longer stretches of discourse, such as chapter from a textbook, the purpose of this activity is to quickly determine the structure of the piece and to identify the key ideas (Celce-Murcia, 1991).

Tudor (1989) gives five other categories of Content-related pre-reading activities (a) pre questions to be answered after reading the text; (b) pre questions to activate the reader's knowledge about the topic; (c) content organizers (e.g., summaries); (d) predictions based on the title, subheadings, illustrations, or skim reading of the text; and (e) integrated reading preparation (combining the above). Taglieber (1988) found the last two activity-types (viz. Using illustrations to make predictions, and formulating questions) to be more effective in facilitating EFL student's comprehension than vocabulary pre-teaching. This result is interesting, since it indicates that heightened background knowledge can enable students to use contextual clues to overcome specific vocabulary deficiencies.

Taglieber (1988) has indicated three major problems that interfere with reader's comprehension.

1. Lack of vocabulary.

2. Difficulty in using language cues to meaning.

3. Lack of conceptual knowledge.

She claimed that the following practical preceding activities may help address these problems:

1. Pictorial context

2. Pre-questioning

3. Vocabulary Pre-teaching

\section{Pictorial Context}

Illustrations can be an integral part of ESP courses. The justification is that they make ESP courses more tangible and understandable. Robinson (1991:62) asserted, “ as well as print material ... one would expect that for teaching ESP there would be a rich supply of authentic visual and mechanical material"; however, he believed that there is not a great deal of discussion of this in the literature.

In this regard, Wilson (1986) refereed to visual support for the avoidance of problems in the comprehension. She also suggested that visual aids may be exploited as a kind of elicitation strategy.

Furthermore, she favored a classroom in which students use illustrations to fulfill a specific task.

Ellis (1993:26) stated, “ visual stimuli, like verbal stimuli, are organized in comprehension and memory” He further added that the organization for visual stimuli is a consequence of perceptual processing, which is bottom -up, or data-driven, in its earlier stage, but top-down processing is affected by conceptual knowledge later on.

As a supporting basis for teaching through illustration, Paivio (1971) proposed the dual coding theory of learning from words and pictures. The theory proposes that learners can construct three types of connections when they are presented with verbal and visual material. McDaniel and Waddill (1994) conducted a research to find out the extent to which pictures can enhance recall of textually presented information, particularly item specific (detailed) information and relational information. They concluded that providing readers with the requisite comprehension abilities to begin with, pictures enable the extraction and under ordinary circumstances do not encode effectively.

\section{E. Pre-questioning}

The questions we are discussing here in pre-reading stage are not intended to test. Their purpose is to make students aware of the way language is used to convey meaning, the questions are not necessarily different from questions in tests, but their purpose and the way they are used is quite different. Nuttal (1982:160) suggests signpost questions would be of great help in pre-questioning. A signpost stands at a crossroads to show travelers the way.

In using signpost questions in pre-reading stage Nuttal (1982) states that you can ask an easy SPQ on the whole text, as an initial top-down activity; and / or you can ask one for each section. Write the SPQ on the board and ask class to read the text silently and find answer. After silent reading, perhaps followed by group discussion check whether they have been able to do this. If a fair number have not, leave it open and explain that you will return to it later avoid giving an answer yourself if you possibly can. Pre-questioning is taught by having the instructor ask questions about a passage and the students answer the questions, through pre-questioning students set purposes for reading, the method is supported by (Johnson, 1981). 


\section{F. Vocabulary Pre-teaching}

In recent years, authorities in the field of teaching English have rejected the idea of learning vocabulary out of context. Richards (1985) stated that words are organized into an intricate, interlocking system; therefore, they cannot be learned in isolation without considering their related context.

Now this question arises: What kind of context is appropriate for vocabulary pre-teaching? Carter and McCarthy (1988) stated that one cannot pin-point a certain treatment or approach to be the best for all situations and for every level of language knowledge. The student's proficiency level and the nature of the course inevitably demand a certain way of treating this component of language.

Explicit vocabulary development and pre-reading activities are very useful when the text or content can be specified. However, what is also required is for teachers to ensure that students use appropriate strategies to increase their recognition vocabulary when confronted with unfamiliar texts. Tudor (1989) states that for the ESP teacher, a popular approach to this problem is to pre teach the vocabulary required for a specific text. Vocabulary pre-teaching is only one of the possible ways in which the ESP teacher can assist in the activation of appropriate content schemata so as to improve the student's comprehension of texts (Tudor, 1982).

\section{G. Sub-technical Vocabulary}

In ESP courses students often have difficulty not with the technical jargon (which usually has a unique L1 equivalent, familiar to students from their specialized studies), but with the common core of semi-technical words that occur in most disciplines.

Troublemakers are words like average, approximate, effect, combination, determine. They are needed in most fields of study and are therefore worth attention. The problem, however, is conceptual rather than linguistic. To make sure the concept has been grasped, ask students to give concrete examples, or offer examples yourself, getting the students to distinguish one that illustrates the concept from one that does not (Nuttal, 1982:67).

Vocabulary Pre-teaching is only one of possible ways in which the ESP teacher can assist in the activation of appropriate content schemata, So as to improve the students comprehension of text (Tudor, 1982).

\section{H. ESP Reading Comprehension}

In a university setting where the medium of instruction and communication is not English, but where students are required to read textbooks in English, there is a need for reading comprehension courses in English for specific purpose (ESP). The texts assigned in academic content-courses require a high level of linguistic proficiency and presuppose extensive background knowledge. Spector, Krischner \& Wexler (2001) argued that this compounded problem is particularly acute in the first year of undergraduate programs, since students are not familiar with the academic jargon and conceptual issues of their respective field.

AbdulGhani (1993) states that unfortunately, reading comprehension, especially in the ESP field, is too often kept at the low level of recalling information learned or of simply locating information explicitly stated in a text. This is partly due to the fact that the language teacher finds the scientific content difficult to tackle in depth. Also, in an ESP course the main emphasis is on language use, language functions, and terminology; thus, content is kept at a low level so as not to constitute an obstacle that interferes with language teaching. In addition, comprehension questions are manipulated to elicit certain grammatical structures or language functions. The question is: Is this really reading comprehension?

When designing a reading course, it is extremely important to strike a balance between content and language. Questions asked about the content must vary in their cognitive level to allow for intellectual involvement on the part of the student (Abdul Ghani, 1993:45). Celece-Murcia (1991) states that ESP academic reading courses should emphasize both reading to learn (activities that stress comprehension of subject matter content) and learning by doing (activities that call for utilization of the ideas in the text. The former deals with the text at hand, exclusively the latter takes the learner beyond the text and into some kind of reformulation of the facts, information and concepts found in it, for example in reading to learn, emphasis is given to close reading of texts, often paragraph by paragraph, in order to find the function which each paragraph fulfils in the passage.

Does the paragraph contain the author's main thesis, supporting ideas, transition to another theme or what else?

Reading to learn also involves complex thinking skills in which students must be able to make the material their own through activities which guide them into analyzing texts, such as summarizing passages and chapters, finding comparison and contrast or cause and effect examples, following an argument in the text (Celce - Murcia 1991:.200).

Many of the reading -to- learn activities lend themselves to thematic or topic - centered reading in which a set of material is composed of a variety of passages, all with common subject area focus. By reading in depth around a particular subject area, students experience marked growth in background knowledge (Dubin \& Bycina, 1991).

Learning by doing activities help students extract meaning from texts by using note-taking skills, following directions. Solving problems set up in the text and similar methods. By manipulating the data, learners gain more experience with the language as well as with the underlying organizational systems presented in the material.

\section{DESIGN}

Forty undergraduate engineering students have been chosen among 70 volunteers through administrating of a 
Michigan Test, the Pre-test allowed the homogenized students to enter the study, then these students have been divided into experimental and control group in which the former received treatment which was employing pre-reading activities and the latter didn't receive any treatment.

\section{A. Participants}

The participants of this study were 40 students from Razi University majoring in engineering courses in the fourth and the fifth terms who were supposed to possess enough linguistic knowledge and had passed general English I.

\section{B. Procedure}

As mentioned in the previous sections, two groups of students with the same range of language proficiency were selected from the engineering departments of Razi University. This was carried out through the administration of Michigan proficiency pre-test. These two groups were randomly assigned into experimental and control groups. The experimental group received treatment, while the control group didn't, the treatment consisted of three different pre-reading activities (a) pictorial context (b) vocabulary pre-teaching (c) pre-questioning. There was also a control -condition, in which there was no pre-reading activity. In the pictorial context condition a picture about the content of the reading passage was shown to the students, then the researcher encouraged discussion by having them describe the content of the picture on the basis of which finally make a guess about the content of the reading passage. In the vocabulary pre-reading condition participants were taught a number of sub-technical vocabularies and-vocabulary of ideas from the reading passages.

The researcher presented these words on the board in meaningful sentences, students took turns reading the sentences and predicting meaning of words, when a word was not adequately defined, it was defined through class discussion.

Pre-questioning consisted of giving participants a one-sentence oral summary of the reading passage and asking them to formulate some questions that they thought the passage might answer, for example, for the "oil" passage researcher said "This text contains a story about oil, what questions do you have that you think the story might answer? Make a list of your questions on the paper in English or in Farsi, then questions were written on the board, where they remained while the students read the passage." This technique combines pre-questioning with receiving very short summary, which then directs students self generated pre-questioning, without a short summary pre-questioning would be vague and abstract.

These pre-reading activities were carried out in five sessions for experimental group, each activity lasted 10 minutes and was carried out immediately before the reading task when participants in the control group received a passage, they began reading task immediately after receiving their instructions for a full account of practical employment of these pre-reading activities.

At the end of the experiment a post-test on reading comprehension was administered to both of the groups. It was aimed at measuring the reading performance of the participants to see if the treatment had made any difference in the reading performance of the two groups. The results obtained through post-test were to be analyzed and interpreted statistically by T-test. Post-test was composed of two booklets each including two texts with 20 comprehension questions, one of the booklets including pre-reading section. Utilizing vocabulary pre-teaching and pictorial context, which was distributed among experimental group and the other booklet had no pre-reading section for control group. Each group was required to answer the questions in 40 minutes. The means of the post-test obtained scores were compared through the T-test statistical procedure to help determine how confident the researcher can be that the difference are not due to chance. In addition, a problem to the nature of all tests of this kind is the effect of chance. To avoid this problem, the students were penalized one-fifth of a correct answer for every wrong one. This could help keep the genuine effect of the treatment.

\section{RESULTS AND DATA ANALYSIS}

To analyze the data obtained through the post-test, the T-test procedure was employed and the following results reported:

TABLE 1

MEAN VARIANCE AND STANDARD DEVIATION FOR EXPERIMENTAL AND CONTROL GROUPS

\begin{tabular}{|c|c|c|c|c|}
\hline Groups & Number & Mean & Variance & Standard deviation \\
\hline Experimental & 20 & 9.68 & 12.98 & 3.60 \\
\hline Control & 20 & 6.02 & 9.54 & 3.09 \\
\hline
\end{tabular}


TABLE 2.

STATISTICAL SUMMARY OF THE RESEARCH

\begin{tabular}{|lc|}
\hline Statistical hypotheses & $\mathrm{H} 0$ :tobs $<$ tcrit \\
& $\mathrm{H} 1$ :tobs $>$ tcrit \\
Alpha decision level & $\mathrm{a}<.05$ \\
Number of participants & $\mathrm{N}=\mathrm{Ne}+\mathrm{Nc}=40$ \\
Observed statistic & tobs $=3.45$ \\
Degree of freedom & $\mathrm{N}-2=38$ \\
Critical value & 2.04 \\
& At a $<0.05$ df 38 \\
Results & tobs $>$ tcrit \\
\hline
\end{tabular}

\section{CONCLUSION}

The present study intended to investigate the effects of pre-reading activities in reading comprehension of a group of students involved in the area of science and technology. In this respect the following question was under consideration:

Will comprehension be facilitated if students are instructed through restoring to pre-reading activities?

To carry out this research, participants were selected on the basis of Michigan test of English proficiency, and were put in one control group and one experimental group. Members of each group were randomly assigned to one of the two following testing conditions:

Experimental group was instructed and tested through restoring to pre-reading activities. Control group was taught in the normal way without restoring to pre-reading activities.

T-test was employed as for the purpose of data analysis. The calculated T-test proved that better comprehension can be gained through restoring to pre-reading activities. In fact experimental group which was exposed to pre-reading activities gained considerable abilities in comprehension than control group. The computation and analysis of the T-test provided us with the judgment to reject the null hypothesis of this study that employment of pre-reading activities would not significantly improve ability in ESP reading comprehension.

Results of this study indicated that giving prior information through restoring to pre-reading activities might become a useful tool for teachers of ESP to facilitate the learner's reading comprehension ability.

The results of this study also, provided empirical answers for the research question posed, and stressed the effectiveness of employment of pre-reading activities in ESP reading comprehension ability.

\section{Pedagogical Implications}

Although much has been said about reading comprehension in a first or second language, most writers conclude that we really know very little about the reading process and perhaps less about what should be done in first or second language to facilitate it.

Mayer (1994:135) asserts, "although the potential advantages of visuals have been extolled by instructional designers, research on illustrations and animations is far from complete." The percent study may provide some support for the idea that visual aids can have powerful effects on learning under certain circumstances. Illustrations, vocabulary pre-teaching and pre-questioning can boost the students' interest and help them construct mental models for the incoming text.

As it was mentioned earlier this study intended to investigate the effects of pre-reading activities on reading comprehension. Findings of this research paved the way for acceptance of the belief that giving prior information of a text through restoring to pre-reading activities can have a large impact on reading comprehension. Providing background knowledge through pre-reading as well as previewing content for the reader seems to be the most obvious strategies for ESP teacher to come up with the problems students have in reading comprehension.

The major implication to be drawn from this research is that students need to activate prior knowledge of the topic before they begin to read, if student do not have sufficient prior knowledge, they should be given at least minimal background information from which to interpret the text. Asserting the main points of the text, providing the readers with the meaning of complicated sub-technical words and expressions, and posing signpost questions prior to the task of reading can lead, to a great extend, to success in their comprehension. One of the implications of this study for ESP syllabus designers is to take care of some pre-reading activities which proved to have positive effect for ESP reading comprehension in this study such as the vocabulary pre-teaching section including a list of definition and explanation of complicated sub-technical vocabularies, concrete illustrations and pictures, some global signpost questions at the beginning of each lesson in engineering materials. Of crucial relevance to the present study is schema theory which asserts that activating, or building reader's existing knowledge prior to reading would improve reading comprehension. Eskey (1988) believes that new information, new concepts, new ideas can have meaning only when they can be related to something the individual already knows.

To sum, the teacher's major role in ESP is to recognize the importance of pre-reading activates in building of related information in such a way that the new material is easily assimilated in to the learner's existing field of knowledge. Since comprehending a text is an interactive process between reader's background knowledge and the text, it is the teacher's role to give sufficient language and context clues through restoring to pre-reading activities such as vocabulary pre-teaching, per questioning and pictorial context to each class of readers to process and activate the relevant schemata necessary for comprehension of the text. 


\section{REFERENCES}

[1] Abdul Ghani, Salwa. (1993). ESP Reading: some implications for design of materials. English Teaching Forum, 7, 42-45.

[2] Adams, J. A. \& Dwyer, M.A. (1982). English for academic uses. Englewood Cliffs, NJ: Prentic - Hall.

[3] Alderson, C. (1984). Reading in a foreign language: a reading problem or a language problem. In Alderson, C\& urquuhart, A. H. (Eds.), Reading in Foreign language (pp. 114-141). London: Longman.

[4] Alderson, Charles J. \& Urquhart.A. H. (1984). Reading in a foreign language. London: Longman.

[5] Alderson, J. C. \& Urquhart, A. H. (1983). The effect of background discipline on comprehension: a pilot study. in A. Hughes \& D. porter (Eds.), Using reader's background knowledge in language teaching. (pp. 125-124). London: Macmillan.

[6] Allen, F.V. (1983). Techniques in teaching vocabulary. Oxford: Oxford University Press.

[7] Anderson, N. (1999). Exploring second language reading. Boston: Heinle \& Heinle.

[8] Aron, H. (1986). The influence of background on memory for reading passage by native and non-native readers. TESOL Quarterly, 20, 13-140.

[9] Barnett, M. A. (1989). More than meets the eye. Foreign language reading. Englewood Cliffs, NJ: Center for Applied Linguistics.

[10] Barr, P., Clegg, C. \& Wallace,C. (1981). Advanced reading skills. London: Longman.

[11] Bartlett, F. C. (1932). Remembering. London: Cambridge University Press.

[12] Beech, J. \& Colley, A. (1987). Cognitive approaches to reading. Chichester: John Willing and Sons.

[13] Benitez, L., Castrillo, J. M, Cerezal, N. \& Suarez, C. (1988). Reading tasks. London: Longman.

[14] Bidaaahri, P., Fallahi, M., Haghani, M. \& Maftoon, P. (2001). English for students of engineering. Tehran: SAMT.

[15] Block, E. L. (1992). See how they read: comprehension monitoring of L1 and L2 readers. TESOL Quarterly, 26, 319-43.

[16] Brandsford, J. D. \& Franks, J. J. (1971). The abstraction of linguistic ideas. Cognitive Psychology, 2, 33-350.

[17] Briggs, Sarah. \& Mary, Span. (1997). The university of Michigan Examination for the Certificate of Proficiency in English. Oxford: Oxford University Press.

[18] Brown, H. D. (1987). Principle of language learning and teaching. Englewood Cliffs, NJ: Prentice Hall.

[19] Browen, J. D., Masdsen, H., \& Hilferty, A. (1985). TESOL: Techniques and procedures. NJ: Newbury House Publishers, Inc.

[20] Call, J. S. (1996). Stages of reading development. FortWorth, Texas: Hartcourt Brace \& Company.

[21] Carrell, P.L. (1983). Three components of background knowledge in reading comprehension. Language Learning, 33, $183-207$.

[22] Carrell, P.L. (1984). Schema theory and ESL reading 'classroom implications and applications. Modern Language Journal, 68, 332-342.

[23] Carrell, P.L., Devine J. \& Eskey, D. E. (1988). Interactive approaches to second language reading. Cambridge: Cambridge University Press.

[24] Carrell, P. L. (1987). Content and Formal Schemata in ESL reading. TESOL Quarterly, 21 (3), 461-481.

[25] Carrell, P. L. (1988). Schema interference in ESL reading. in Carrell, P. L., Devine, J. and Eskey, D. E. (Eds.), Interactive approaches to second language reading (pp. 128-142). Cambridge: Cambridge University Press.

[26] Carrell, Patricia. L. (1985). Three components of background knowledge in reading comprehension. Language Learning, 33, 183-203.

[27] Carrell, P.L. (1989). Metacongnitive strategy Training for ESL Reading. TESOL Quarterly, 23, 647-673.

[28] Carrell, P.L. \& Eisterhold, J.C. (1983). Schema theory and ESL reading Pedagogy. TESOL Quarterly, 17, 553-573.

[29] Carter, R. \& McCarthy, M. (1988). Word list and learning words: Some foundations. In R. Carter \& M. McCrth (Eds.), Vocabulary and language teaching (pp. 86-112). Essex: Longman Group.

[30] Casanave, Christine. (1983). Comprehension Monitoring in ESL Reading A neglected Essential. TESOL Quarterly, 22,283-301.

[31] Celce-Murcia, Marianne. (1991). Teaching English as a second or foreign language. Massachusetts: Heinle \& Heinle publishers.

[32] Chastain, K. (1988). Developing second language skills: Theory and practice (3rd ed.). Chicago: HBJ.

[33] Coady, James. (1979). A Psycholinguistic modal of the ESL reader. Rowley, Massachusetts: New bury house publishers.

[34] Davies, D., Bathurst, D. \& Bathurst, R. (1990). The telling image. Oxford: Claredon Press.

[35] Davis, F. (1995). Introducing Reading. London: Penguin English.

[36] Dubin, F. \& Bycina, D. (1991). Academic reading and the EFL/ESL teacher. In celce - Murcia, M. Teaching English as a second or foreign language (pp.195-215). New York: Heinle \& Meinle publishers.

[37] Duffy, G. G. (1988). Modeling mental processes helps poor readers become strategic readers. The Reading Teacher, 41, 762-767.

[38] Dutta, K. Sujit. (1994). Predicting as pre-reading activity. English Teaching Forum, 7, 39-49.

[39] Ellis, S. R. (1993). Pictorial communication in virtual and real environment. New York: Taylor \& Francis.

[40] Eskey, D. (1988). Holding in the bottom: An interactive approach to the problem of sound language readers. In (Carrell, P. L., Devine, J. and Esky, D. E. Eds.), Interactive approaches to second language learning. (pp. 130-152). New York: Cambridge University Press.

[41] Eskey, D. E. (1999). Reading and the teaching of L2 reading. TESOL Journal, 11, 5-9.

[42] Gibbs, R. (2001). Authorial intentions in text understanding. Journal of Discourse Processes, 32, 73-80.

[43] Gibbs, R., Kushner, J. (1991). Authorial intentions and metaphor comprehension. Journal of Psycholinguistic, 20, 11-30

[44] Goodman, K.S. (1967). Reading: a psycholinguistic guessing game. Journal of Reading Specialist, 6. 126-135.

[45] Goodman, K.S. (1970). Reading: a psycholinguistic guessing game. In Gunderson, D. U. (1970). Language and Reading (pp. 11-21). An Interdisciplinary Approach (pp.107-119). Washington, D. C. Center for Applied Linguistics.

[46] Goodman, K. S. (1988). The reading process. In carrell, P.L. et al. (Eds.), Interactive Approaches to Second language reading. (11-21) New York: Cambridge University Press

[47] Goodman, K.S. (1981). Psycholinguistic universal in the reading Process. In Pimsleur \& R. T. Quinn (Eds.), the Psychology of second language learning (pp.135-142). Cambridge: Cambridge University Press. 
[48] Grabbe, W. (1991). Current developments in second language research. TESOL Quarterly, 25, 375-406.

[49] Greenall, S. \& Swan, M. (1986). Effective Reading. Cambridge: Cambridge University Press.

[50] Grellet, F. (1981). Developing reading skills. A practical guide to reading comprehension exercises. Cambridge: CPU.

[51] Hansen, J. (1981). An inferential comprehension strategy for use with primary garden children. The Reading Teacher, 34, 665-669.

[52] Hayashi, K. (1999). Reading strategies and extensive reading in EFL classes. RELC Journal, 1, 114-132.

[53] Hudson, T. (1982). The effects intended schemata on the "short circuit" in L2 reading: Non decoding factors in L2 reading performance. Language learning, 32, 1-31.

[54] Hudson, T. (1991). A content comprehension approach to reading English for science and technology. TESOL Quarterly, 25, 77-85.

[55] Hutchinson, T. \& Waters, A. (1987). English for specific purpose. Cambridge: Cambridge University Press.

[56] Jannuzi, C. (1997). Key concepts in FL literacy: Schema theory. Literacy Across Cultures. Vol. 1, No. 2. (September 1997) Available online at: http://www.aasa.jp/-dcdycus/LAC97/schema997.htm.

[57] Johnson, P. (1981). Effects on reading Comprehension of language complexity and cultural background of a test. TESOL Quarterly, 15, 169-181.

[58] Johnson, P. (1982). Effects on reading comprehension of building background knowledge. TESOL Quarterly, 16, 503-516.

[59] Johnson, K. (1981). Communicative in writing. Harlow: Longman.

[60] Kim, H. \& Krashen, S. (1997). Why don't language acquirers take advantage of the power of reading. TESOL Journal, 6, 26-28

[61] Krashen, Stephen. (1981). Second language acquisition and second language learning. New York: Pergamon Press.

[62] Krashen, S. (1982). Principles and practice in second language acquisition. Oxford: Pergamon.

[63] Lorch, R. F., Lorch, E. P. \& Kluswitz, M. A. (1993). College Students conditional knowledge about reading. Journal of Educational Psychology, 85 (2), 239-252.

[64] Marshall, Steward. \& Gilmour, Marion. (1993). Lexical knowledge and reading comprehension in Papua New Guinea. English For Specific Purpose, 12, 69-81.

[65] Mayer, R. E. (1994). Visual aids to knowledge construction. In Wolfgang Schontz \& Raymond W. Kulhavy (Eds.), Comprehension of Graphics (pp.120-134). North-Holland: Elsevier Science B. V.

[66] McDaniel, M. A., \& Waddill P.J. (1994). The benefit of pictures in text. In Wolfgang Schontz \& Raymond W. Kulhavy (Eds.), Comprehension of Graphics (pp.82-99). North-Holland: Elsevier Science B. V.

[67] Miller, Linda.\& Linn, Michael. (1992). Linguistics for teachers. New York: Mc Graw-Hill, Inc.

[68] Mohammed, M. A. H. \& Swals, J. M. (1984). Factors affecting the successful reading of technical instructions. Reading in a foreign language, 2,2 .

[69] Munby, J. (1978). Communicative Syllabus Design. Cambridge: CUP.

[70] Nelson, Geyle.\& Schmid, Thomas. (1989). ESL Reading: Schema Theory and standardized Tests. TESOL Quarterly, 23, 537-543.

[71] Nuttal, Chriatine. (1982). Teaching reading skills in a foreign language. Oxford: Macmilan Publishers.

[72] Oller, J. W. (1995). Adding abstract to formal and content schemata: Results of a recent work in Peircean semiotics. Applied Linguistics, 16 (3), 273-306.

[73] Omaggio, A. C. (1979). Picture and second language comprehension: Do they help? Language Learning, 29, 152-163.

[74] Paivio, A. (1971). Imagery and verbal processes. New York: Holt, Rinehart \& Winston.

[75] Paran, A. (1997). Bottom-up and Top-down Processing. Available online. at: http://www.rdg.ac.UK/AcaDepts/cl/CALS/buptdown.html

[76] Paulston, C. B. \& Bruder, M. N. (1976). Teaching English as a second language: Techniques and procedures. Cambridge, MA: Winthrop.

[77] Pearson-Casanre, R. Christina. (1984). Communicative pre-reading activities: Schema theory in action. TESOL Quarterly, 18, p. 334-336.

[78] Perfetti, C.A. (1984). Reading ability. New York: Oxford University Press.

[79] Raims, A. (1983). Techniques in Teaching writing. New York: OUP

[80] Resnick, L. B. \& Weaver, P. A. (1979). Theory and practice of early reading. Volumes I -III. Hillsdale, NJ: Erlbaum.

[81] Richards, J. C. (1985). The context of language teaching. Cambridge: Cambridge University Press.

[82] Richards, J. C., Theoder, S. R. (1986). Approaches and methods in language teaching: A description and analysis. Cambridge: Cambridge University Press.

[83] Richards, J. C., Platt, J \& Platt, H. (1992) Longman dictionary of language \& applied linguistics. New York: Richards Clay.

[84] Rivers, Wilga M. (1987). Interactive language teaching Cambridge: Cambridge University Press.

[85] Rivers, Wilga.M. (1981). Teaching foreign language skills in a foreign language skills. Chicago: University of Chicago Press.

[86] Robinson, P. C. (1991). ESP today: A practitioner's guide. NY London : Prentice Hall.

[87] Royer, J. (1984). Learning from text: methods of affecting reader's intent. Journal of Reading Behaviors, 15, 33-50.

[88] Rumelhart, D.E. \& Ortony, A. (1997). The representation of knowledge in memory. In R. C. Anderson, R. J. Spiro of WiE. Montague (Eds.), schooling and acquisition of knowledge (pp. 99-135). Hillsdale, NJ: Lawerance Erlbaum.

[89] Rumelhart, D. E. (1981). Schemata: The guiding blocks of cognition. In J.T. Guthrie (Ed.), comprehension and teaching: Research reviews (PP.3-26). Newark, DE: International reading association.

[90] Seliger, H. W. (1972). Importing reading in English as a second language. English Teaching Journal, 27, 48-55.

[91] Shih, M. (1992). Beyond comprehension exercises in ESL academic reading class. TESOL Quarterly, 26 (2) 289-317.

[92] Smith, F. (1971). Understanding Reading: A psycholinguistic Analysis of Reading and learning to read. New York: Holt. Rinehart and Winston.

[93] Smith, F. (1982). Understanding Reading. 3rd Ed. New York: Holt, Rinehart, and Winston.

[94] Sola Maria, Anna. (1996). EFL Reading: An Outlining Teaching. English Teaching Forum, 12, 48-50.

[95] Spector, E., Kirschner, M., Wexler, C. (2001). Designing ESP reading courses at the university level. English For Specific 
Purposes, 20, 367-386.

[96] Stanovich, K. E. (1980). Attentional and automatic context effects in reading. In A. M. lesgold \& C. A. Perfetti (Eds.), Interactive Processes In Reading (pp.241-267). Hillsdale, NJ: Lawrence Erlbaum.

[97] Swales, J. M. (1971). Writing Scientific English. London: Nelson.

[98] Swales, J. M. (1980). ESP: The textbook problem. ESP Journal, 1, 11-23.

[99] Tagliebar, K. Loni.(1988). The effect of Pre-reading activities on EFL reading comprehension. TESOL Quarterly, 22, 455-472.

[100] Trimble, L. (1985). EST: A course approach. Cambridge: CUP.

[101] Tudor, I. (1989). Pre-reading: A categorization of formats. System, 17, 323-328.

[102] Ur, P. (1996). A course in language teaching: practice and theory. Cambridge: CUP

[103] Wallace, C. (1992). Reading. Oxford: OUP.

[104] Widdowson, H. G. (1979). Explorations in Applied Linguistics 1. Oxford: Oxford University Press.

[105] Widdowson, H. G. (1983). Learning purpose and language. Oxford: Oxford University Press.

[106] Widdowson, H. G. (1984). Explorations in Applied Linguistics 2. Oxford: Oxford University Press

[107] Widdowson, H. G. (1990). Aspects of Language Teaching. Oxford: Oxford University Press.

[108] Williams, Eddie. \& Moran, Chris. (1989). Reading in a foreign Language at intermediate and advanced levels with particular reference to English. ELT, 22,217-227.

[109] Williams, R. (1985). Teaching vocabulary recognition strategies in ESP reading. The ESP Journal, 4, 121-131.

[110] Wilson, J. (1986). Task-based language learning. In David Harper (Ed.), ESP for the university (pp.26-43). Oxford: Macmillan Education.

[111] Yorio, C. A (1972). Some source of reading problems for foreign language learners. Language Learning, 21,107-115.

[112] Yule, G. (1985). The study of language. Cambridge: Cambridge University Press.

[113] Zhenhui, Rao. (2001), Teaching Reading: Fitting a top-down strategy in to the Chinese context. Guidelines, 23, 20-24.

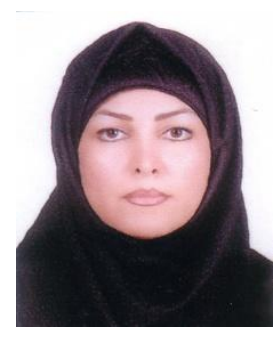

Minoo Alemi is a Ph.D. candidate of TEFL at Allameh Tabataba'i University. She is also a faculty member and vice-Dean of Education at Languages and Linguistics Department at Sharif University of Technology. She has taught English courses for over a decade at different universities in Tehran. Moreover, she has published many articles in international journals and more than ten English textbooks for GE and ESP courses.

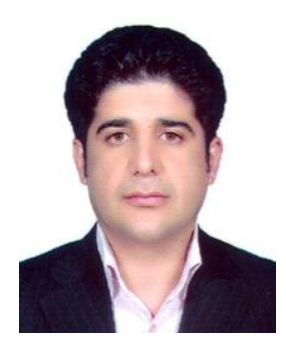

Saman Ebadi is a Ph.D. candidate at Allamaeh Tabatabei University, Tehran, Iran. His areas of interest are sociocultural theory, dynamic assessment, CALL, CMC, language acquisition, and syllabus design. He has published and presented papers in international conferences and journals. 